\title{
Respect for cultural diversity as a global bioethical principle. Own reasons from a Protestant perspective
}

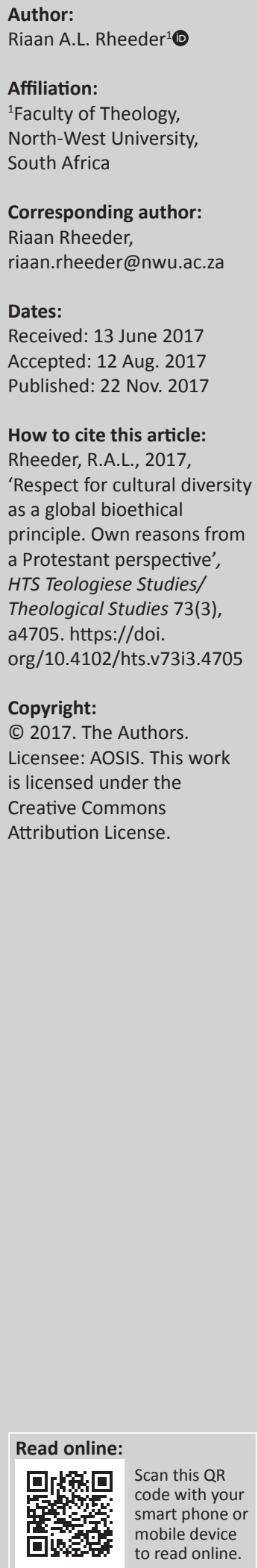

\begin{abstract}
In the development and acceptance of Article 12 of the Universal Declaration of Bioethics and Human Rights, the United Nations Education, Science and Cultural Organization (UNESCO) did not involve the Protestant faith tradition in the consultation process (other traditions were indeed consulted). This brings the universality (UNESCO perspective) as well as the acceptability of the Declaration and its principles (democratic perspective) into question. In order to address this issue, it is necessary to involve the Protestant tradition in the discourse by presenting own reasons that support the universal principles in the Declaration (theological perspective). This discourse has shown that respect for cultural diversity, pluralism and the priority of universal shared values can be grounded from a Trinitarian perspective; therefore, the appeal of the Declaration to consider this principle seriously in the field of bioethics can be supported by the Protestant religious tradition.
\end{abstract}

\section{Introduction}

In 2005, the United Nations Education, Science and Cultural Organization (hereafter UNESCO) accepted the universal bioethical principle and human right of Article 12 of the Universal Declaration of Bioethics and Human Rights (hereafter UDBHR or 'Declaration'), which reads as follows:

The importance of cultural diversity and pluralism should be given due regard. However, such considerations are not to be invoked to infringe upon human dignity, human rights and fundamental freedoms, nor upon the principles set out in this Declaration, nor to limit their scope. (UNESCO 2006)

For the first time in the history of bioethics, it was expected that respect for cultural diversity and pluralism had to be taken into account in the global bioethical discourse. One of the achievements of the UNESCO Declaration is that respect for cultural diversity and pluralism was accepted as a universal ethical principle (Ten Have \& Gordijn 2014:829-834). In 2005, the UDBHR was unanimously accepted (without any notated dissentient vote, reserve or qualification) by all member states (IBC 2008:45; Ten Have \& Jean 2009:17). The Declaration, with its 15 bioethical principles, is therefore not only the first in the history of bioethics to which almost all the governments in the world, including South Africa, have committed themselves but also currently the only bioethical (political) text to have this status (UNESCO 2005).

The research problem from a UNESCO, democratic and theological perspective is indicated by Tham (2014:2-3), a Roman Catholic bioethicist. Regarding the perspective of UNESCO, Tham finds a shortcoming in the claim to universality, saying that only one short opportunity was afforded to religions (Islam, Confucianism, Buddhism, Hinduism, Roman Catholicism and Judaism) to make an official contribution to the development of the Declaration (Gallagher 2014:135; IBC 2004:2-4; Ten Have \& Jean 2009:31). Further, Tham emphasises that Protestants made no contribution to the development of the UDBHR. Ten Have (2016), previous director of the Division of Ethics of Science and Technology at UNESCO, confirms the dilemma as follows:

It is clear that given the short time frame for drafting the Declaration, the development of the text and the
resulting consensus has been vulnerable to criticism since not all relevant actors could be consulted while
others did not feel represented by the experts involved. (p. 102) To be truly credible and representational, support from a selective group of religions cannot exclusively serve as consent to a global bioethics. From a UNESCO perspective, it is important to make the UDBHR (and Art. 12) more representational of religions and thus broaden the claim to universality.

From a democratic perspective, however, it is also important to make the Declaration more representational of the religions in a specific state. It has to be kept in mind that the UDBHR describes itself as 'universal principles based on shared ethical values' in its Foreword 
(UNESCO 2006). These principles are also known as 'common morality' and form an independent meta-ethical theory. What are shared values? John Rawls (1993), an American political philosopher in the liberal tradition, gives the following answer to the question:

Since justification is addressed to others, it proceeds from what is, or can be, held in common; and so we begin from shared fundamental ideas implicit in the public political culture in the hope of developing from them a political conception that can gain free and reasoned agreement in judgment, this agreement being stable in virtue of its gaining the support of an overlapping consensus of reasonable comprehensive doctrines. (pp. 100-101; cf. also Wenar 2017)

Firstly, Rawls (1993:144) acknowledges that pluralism is a permanent historical reality that cannot be ignored. Each reasonable citizen has his or her own view about God and life, right and wrong, good and bad (reasonable comprehensive doctrines). He is convinced, however, that this reasonable pluralism does not wish to impose values upon others, but rather strives after shared values and is built on the viewpoint that diverse ethical traditions share minimum ethical values based on consensus. According to Rawls, this pluralism is known as 'overlapping consensus' or 'political conception' (Ten Have 2011:25; Wallace 2009:55-68). The reason for using shared values is that it is not grounded in any specific philosophy or religion. They emanate from the 'political culture' and have the special value that supporters of diverse ethical theories can agree on bioethical principles, as was clearly shown by the acceptance of the Declaration (cf. also Gallagher 2014:135; Ten Have 2011:23).

Secondly, the question of legitimacy remains, namely why would the global community (also those with a Protestant religious tradition) give their consent to shared bioethical values? According to Rawls (1993:134), diverse ethical traditions or groups may support shared values, but they do it because of different or own values: 'In such consensus, the reasonable doctrines endorse the political conceptions, each from its own point of view'. In this way, shared values are confirmed by own moral grounding; thus, the shared values are not experienced as imposition by others, but as part of the own religious system.

Thirdly, Rawls (1993:140-144) is of the opinion that if citizens are unable to give reasons from their own religious tradition of why they support the bioethical shared values, the shared values would not be valid and the social order would disintegrate (Wenar 2017). From another angle, the philosopher Charles Taylor supports this view of Rawls in his influential work The Politics of Recognition (1994). According to Taylor (1994:34), cultural diversity as unique human identity is essential to human existence. When the identities of individuals and groups are intentionally denied, ignored or passed over, it leads to alienation and disillusionment. Maggay (2017:loc 1202-1205) states that one of the reasons why universal values enjoy so little respect in Asian and Arabic countries is the lack of a deep enough philosophical basis for human rights in these cultures'.
The lack of participation and absent own reasons for the universal values of the UDBHR are probably the most important reasons why the Declaration, according to an indepth study by Langlois (2013:154), has had no or very little impact on the bioethical community in democratic South Africa. The own reasons from the Protestant tradition will strengthen the political acceptability of the shared values in the Declaration and can make a contribution to the discourse on cultural practices in South Africa. On the one hand, the serious health risks of some initiation ceremonies can be addressed; on the other hand, a contribution can be made to the promotion of traditional medicine. The community of believers as part of civil society in a democracy can have a great influence in the field of global bioethics. In this connection, Ten Have (2016:21-22) refers to the example where the Tongan government secretly gave permission to Autogen - an Australian biotechnological company - to collect genetic material from the Tongan citizens and to store those in a databank with a view to research in exchange for annual financial support for research and royalties. When the agreement became known, churches (and pro-democratic groups) rebelled against it; they were of the opinion that no informed permission had been given by the citizens and that it posed a great danger for their privacy and confidentiality. In 2001, the project was dismissed (Burton 2002:443).

This article serves as part of a conversation by and with the broad community with a Protestant tradition and it has a dual purpose. On the one hand, the aim is to bring about stronger representation of the UDBHR in the Protestant community; on the other hand, it endeavours to prevent alienation of the Protestant community from the Declaration by presenting own (theological) reasons to emphasise the validity of its principles of the Declaration and, in this way, to strengthen its influence.

The central theoretical statement of this discourse is that sufficient own reasons exist in the Protestant theology to accept Article 12 of the UDBHR and therefore to regard it as part of the calling of the Christian community. 'Protestant' is used in the broad sense of the Christian tradition that originated in the sixteenth century and currently constitutes the third largest Christian tradition - Roman Catholicism and Greek Orthodoxy being the two larger traditions. Protestantism is diverse and comprises diverse viewpoints, but two features form the core of the tradition, namely emphasis on the Word of God (Bible) and protest against injustice, for example, protest in favour of religious freedom (Pauls \& Hutchinson 2008; Van Leeuwen 2014:419-420). Reaching the aim of the article consists of two phases. In the first phase, with a view to indicate own reasons convincingly, the meaning of Article 12 of UNESCO will be investigated and construed. In the investigation, the focus will be exclusively on official material by UNESCO and commentators that interpret the Declaration with the purpose of construing a 'UNESCO perspective' (Martin 2014:119; Shickle 2014:486). In the second phase, having acquired adequate insight into Article 12, it will be theologically evaluated and grounded. 
In order to execute the first phase of the aim, the meaning of Article 12 will now be investigated and construed.

\section{Cultural diversity}

In order to establish own reasons for accepting Article 12, it is important to examine the meaning of the concepts in Article 12. What does Article 12 protect and in what way does it do it? The Bioethics Core Curriculum 1 of UNESCO states that Article 12 should be seen in the following context: 'As a theoretical and practical continuation of Articles 3 and 10, and to be continued in discussion of Articles 13, 14, and 15' (UNESCO 2008:51). This means that this global principle refers to human dignity, equality and non-discrimination.

In the first place, the UDBHR connects human dignity with the norm of respect for cultural diversity, which is confirmed by Article 2(c), which states one of the aims of the Declaration is 'to provide a universal framework of principles' with the specific purpose 'to promote respect for human dignity' (see also Art. 26, UDBHR) (Revel 2009:200; UNESCO 2006). The recognition and execution of respect for cultural diversity gives expression to human dignity and where this principle is respected, people are treated with human dignity (Chuwa 2014:166). In the second place, it is clear that respect for cultural diversity is the logical result of the recognition of the principles of equality of all people as expressed in Article 10 of the UDBHR. Respect for cultural diversity is important because it gives expression to the principle of equality. According to Chuwa (2014:174), in the third place, Article 11 of the UDBHR has to be regarded as a further grounding of Article 12. This principle states that discrimination should not take place against any individual or group, which means that no individual or group may be excluded or given preference to in the context of bioethics. Article 11 does not refer directly to culture, but Article 14 states clearly that no discrimination should take place against a human being on the grounds of religion, which implies that there may be no discrimination against identity and culture (cf. also Rivard 2009:188-198).

The UDBHR introduces the concepts of cultural diversity and pluralism in the verbalisation of Article 12 (Alvarez 2016:781). It is clear that Article 12 acknowledges the importance of cultural diversity and pluralism (Chuwa 2014:166). What is the meaning of culture, cultural diversity and pluralism in the Declaration? 'Despite a very general understanding of the concept of "culture," it remains ambiguous and often means different things to different people', is the opinion of Macklin (2014) in her explanation of Article 12. In explaining what is meant by the concepts of culture and cultural diversity, the Core Curriculum 1 (UNESCO 2008:51), Revel (2009:200) and UNESCO Chair in Bioethics Haifa (2016:103) use the definition as formulated in the Universal Declaration on Cultural Diversity of UNESCO (hereafter UDCD). In the Foreword and in Article 1 of the UDCD, culture and cultural diversity are defined together as follows (UNESCO 2002):

Culture should be regarded as the set of distinctive spiritual, material, intellectual and emotional features of society or a social group, and it encompasses, in addition to art and literature, lifestyles, ways of living together, value systems, traditions and beliefs... Culture takes diverse forms across time and space. This diversity is embodied in the uniqueness and plurality of the identities of the groups and societies making up humankind.

According to these two definitions, cultural diversity refers to the following (cf. also Macklin 2014:154):

1. It is human communities and groups

2. with unique and plural identities

3. shaped by distinctive/diverse features/forms

4. that are spiritual, material, intellectual and emotional in origin

5. and are expressed in art, literature, lifestyle, ways of living together, value systems, traditions and faith.

Although the UNESCO Declaration itself does not explain the concepts, there is an indication that the above-mentioned understanding of cultural diversity is broadly reflected in the thought trend of the Declaration when the following argument in the Foreword (UNESCO 2006) is considered:

Bearing in mind that cultural diversity, as a source of exchange, innovation and creativity, is necessary to humankind and, in this sense, is the common heritage of humanity, but emphasizing that it may not be invoked at the expense of human rights and fundamental freedoms ... Also bearing in mind that a person's identity includes biological, psychological, social, cultural and spiritual dimensions.

In the light of the above definition, both the Core Curriculum 2 of UNESCO (2011:53) and Alvarez (2016:787) acknowledge that religion as a part of the culture of humanity should also be taken into account when defining cultural diversity.

What is meant by pluralism? In this regard, one can refer to Article 2 of the UDCD (UNESCO 2002), which states, '... cultural pluralism gives policy expression to the reality of cultural diversity'. Pluralism can be defined as the acknowledgement and acceptance of cultural diversity in several areas of existence such as politics, science, medicine, medical practices, religion and philosophy (Macklin 2014:157, 160; UNESCO Chair in Bioethics Haifa 2016:97). In the light of the above definition of pluralism by UNESCO, Revel (2009:199, 206) concludes, 'Pluralism is itself a value, a guarantee of coexistence and mutual understanding', and therefore it has to be respected according to Article 12. The verbalisation of Article 12 clearly states that respect for cultural diversity and pluralism is important, which gives rise to the question of why it is important.

Firstly, as has been clearly shown in the above quotation from the Foreword of the Declaration, respect or acknowledgement of cultural diversity is important because as a source of 'exchange, innovation and creativity', it is advantageous to humanity. According to the Foreword of the Declaration, cultural diversity describes the common heritage of humanity', which means all culture has to be regarded as the property of humanity (UNESCO Chair in Bioethics Haifa 2016:96). It means that culture must not be acknowledged as 
the exclusive property of a specific group, but has to serve as a source of exchange, innovation and creativity that can be used to the advantage of humanity.

Secondly, respect for cultural diversity is important for the peaceful coexistence of plural communities. Article 2 of the UDCD states the following (UNESCO 2002):

In our increasingly diverse societies, it is essential to ensure harmonious interaction among people and groups with plural, varied and dynamic cultural identities as well as their willingness to live together. Policies for the inclusion and participation of all citizens are guarantees of social cohesion, the vitality of civil society and peace.

Because cultural diversity forms part of human identity and because it is a global benefit, it has to be taken into account according to Article 12; moreover, without respect for cultural diversity, peace would not be possible.

Different from the other articles in the Declaration, Article 12 has a built-in restriction. According to Ten Have and Gordijn (2014:834), this is the only article in the Declaration that states a restriction. It is therefore regarded as the weakest article in the Declaration as it requires a hierarchical understanding and application of Article 12. Garcia and Monlezun (2016:440) underline the fact that human dignity, human rights and fundamental freedoms are prioritised with regard to cultural diversity in Article 12 (Chuwa 2014:166; Revel 2009:200, 207). Article 12 formulates the viewpoint as follows:

However, such considerations are not to be invoked to infringe upon human dignity, human rights and fundamental freedoms, nor upon the principles set out in this Declaration, nor to limit their scope. (UNESCO 2006)

(This idea is also repeated in the Foreword of the UDBHR and Article 4 of the UDCD.) It means that arguments and practices in the context of health can only be founded on cultural diversity if they are in agreement with the other principles in the UDBHR and human rights (IBC 2013:17; Ten Have 2016:104). Why did UNESCO find it necessary to prioritise human rights, fundamental freedoms and the principles of the UDBHR or to formulate the restriction of cultural activities as ethical guidelines? The basic motivation for the fundamental restriction is found in Article 14 of the UDBHR, which states that 'the enjoyment of the highest attainable standard of health is one of the fundamental rights of every human being'. In practice, it is clear that some cultural practices cannot contribute to this ideal; on the contrary, it is known that some human actions in the cultural environment do not benefit the health of individuals and can cause serious harm to health. For this reason, the UDBHR states the duty of minimalising such harm as far as possible or avoiding it completely (Art. 4, UDBHR; Chuwa 2014:176-177). Ten Have (2016) describes the situation as follows:

Appeals to cultural diversity and accusations of bioethical imperialism are less convincing with growing evidence and awareness of harmful effects. Health is a common value; in this frame there are no benefits, only harms. (p. 203)
Macklin (2014:160-165) draws the attention to a large variety of cultural practices that have serious adverse medical implications for women. Subsequently, in-depth attention will be briefly given to only one practice that may serve as proof of the preference for restriction of cultural practices. In some (traditional) communities, girls of 13 years and even younger are forced to marry much older men. Most of these girls are physically and emotionally immature to a large degree. Some become pregnant quickly, but because of their age they are not physically ready for pregnancy; therefore, pregnancy poses a serious health risk to them. The birth process is very difficult for these girls and in most cases, because of the lack of medical intervention, the young mother dies or experiences lifelong serious physical and psychological consequences. The physical results of pregnancy at a young age are, among others, obstructed labour, which might lead to infection, rupture of the bladder and postpartum haemorrhage. Long-term complications for the mother include obstetric fistula [an opening between the vagina and the bladder]. This medical condition frequently results in the girls emitting an unpleasant odour and therefore being rejected by their husbands for life. 'Early marriage, along with the cultural tradition of arranged marriages, violates human rights related to reproductive health', Macklin (2014:163) concludes. Macklin assigns more weight to three universal ethical and human rights principles of the UDBHR than to cultural practices. Firstly, Article 4 ('Benefit and harm') states that health benefits have to be maximalised and all harm to health minimalised. Secondly, Article 7 ('Persons without the capacity to consent') states that children must participate in the decision-making process in research that poses possible serious medical implications. The explicit statement in Article 7 that children have to give consent or may refuse or withdraw consent to participate in research, implies that children have to give consent or may refuse or withdraw consent to a marriage and procreation that might be detrimental to their health. Thirdly, according to Article 8, vulnerable people have a right to protection against harm.

The above answer that prioritising has been necessary because some cultural practices harm people and do not promote their health does not solve the question of equality. Equality of all people implies that cultural products have equal value and application. The question is if prioritising could mean that specific cultural moral values, for example Western principles (such as articles 4, 7, 8 and 14), are seen as superior and are now transferred to other cultural groups or enforced upon them, in that way trumping cultural practices and values (Ten Have 2016:42). Could it further be asked if the reproach would be true that the bioethical colonising or moral imperialism would be at the bottom of the debate because prioritising amounts to domination of the powerful (Ten Have 2011:129; 2016:202).

A UNESCO answer can be summarised as follows: In the first place, while it is true that respect for cultural diversity gives expression to the principle of equality and therefore has to be held in high regard, the paradox is exactly that if 
cultural diversity is not restricted or subjected to other shared values, cultural practices are not only harmful to people (as shown above) but also encourage global unequal treatment as it works with double standards (Chuwa 2014:167). An example is the above cultural practice that has serious health risks for girls: May girls in a global moral community be treated differently in such a way that one's health is protected and the other one's is impaired? In the second place, the practice to restrict some rights in certain circumstances and to prioritise another claim to promote health is not a strange idea and is applied worldwide (Chuwa 2014:175-177). In the third place, it is put forward that the reproach above does not take into account that the principle of prioritising certain values in Article 12 was not transferred or enforced, but were voluntarily received and accepted by means of negotiation and consensus (Chuwa 2014):

As a legal standard adopted through the United Nations, universal human rights represent the hard-won consensus of the international community, not the cultural imperialism of any particular region or set of traditions, Revel (2009:202) points out. (pp. 168-169)

For this reason, prioritising of global principles as opposed to cultural diversity cannot be seen as a superior moral evaluation or judgement of traditions or cultural practices, but it is based on consent to the shared value that everyone has a right to health (Ten Have 2016:203). In the fourth place, Ten Have (2016:81) remarks, 'Taking moral diversity seriously is inescapable but human existence is not just determined by controversies, disagreements and diversity'. People can develop and share a common vision and ideals, as well as normative practices and images. A very good example is the global recognition that human dignity is a characteristic of all humanity (Chuwa 2014:166, 174).

To execute the second phase of the research to attain the aim stated at the end of Introduction, the meaning of the content of Article 12 construed above will subsequently be evaluated and grounded theologically ethically.

\section{Own reasons}

\section{Grounding}

It is, however, not only important from an UNESCO and democratic perspective to offer own reasons for a shared value but it is also necessary to indicate own reasons from a theological perspective on the reality of diversity. According to Hollinger (2008:64), contrary to the theory of shared values, God is the ground, the norm and the authority of all ethics.

The human rights authority and ethicist in the Protestant tradition, Vorster (2015:109), links the Bible and shared values when he states that the second commandment (Ex 20:4-6) lays down knowledge of and living from the Bible as a duty and then continues:

Hiermee word ten diepste 'n belangrike fundering vir Christelike morele handelinge gelê. Uiteindelik bied die geskrewe Woord die beginsels vir die etiek en is dit ook die toetssteen van alle etiese kodes en handelinge' [With this, at the very base, an important foundation for Christian moral actions is laid. Ultimately, the written Word provides the principles of ethics and it is also the touchstone for all ethical codes and acts].

The Christian testing and grounding (presentation of own reasons) of shared bioethical values is a new development in Protestant ethics that has been introduced by the publication of two books, namely Covenantal Biomedical Ethics for Contemporary Medicine: An Alternative to Principles-Based Ethics by Rusthoven (2014) and The New Testament and Bioethics: Theology and Basic Bioethics Principles by Macaleer (2014). Macaleer (2014:24-30) shows clearly that up to the publication of these two books, no Protestant ethicist has given probing attention to theoretical grounding of modern global bioethical principles. His book treats the Protestant theological grounding of four universal bioethical principles by Beauchamp and Childress (autonomy, beneficence, malfeasance and justice). Macaleer (2014) comments as follows on these principles:

As outlined by Beauchamp and Childress, these principles are based on what they call the common morality. Thus, the principles have no specific theological foundation; this book attempts to give those principles a Scriptural foundation. (pp. ix-x)

According to Rusthoven (2014:201-203), Protestant ethics must 'explore the normativity of the principles of principlism' or shared bioethical values because they do not flow from a Christian or Protestant life and worldview. 'A Christian ethical approach should start with the main question, and that is the question of the theological foundation for human rights and the responsibilities they impose on man,' Vorster (2004:22-24) writes. The same is true of the universal principles of the UDBHR, for which no theological grounding exists. With reference to this truth, the view of Stott et al. (2006:197) is offered that a theological grounding gives moral authority and strength to universal principles (Lorenzen 2009:298) and that it is of special value to the Christian medical doctor, researcher and politician because a Christian grounding forms the religious motivation and impetus for the execution of a human right as shared value. A grounding forms part of 'I believe in' (Waldron 2010:233-234) and can help that human rights and universal bioethical principles live in the heart of the Christian (Vorster 2004:24).

The theological question is formulated as follows by Sheffield (2001):

How, then, should the Christian community think and act in response to cultural diversity ... Does Scripture speak to this issue, or is multiculturalism purely a modern concern ... how do I understand my identity as one who stands in relationship to God and how do I understand and interact with another whose identity is also related to God. (pp. 39, 50)

In their discussion of cultural diversity and identity, as well as human rights, Volf (1996:25) and Vorster (2004:80) say that 
the Trinity forms a Protestant point of departure in the evaluation and grounding of ethical matters. Gibson (2012) writes:

Any theology of diversity must be rooted in the triune nature of God. God as Father, Son, and Holy Spirit is the essence of diversity and unity ... The church as the people of God finds diversity and unity in the whole being of God - Father, Son, and Holy Spirit - three persons and one being. (p. 439)

Heyns (1982:89-109) summarises this point of departure strikingly when he points out that the Father is the creating ground, the Son the recreating ground and the Spirit the eschatological ground of the phenomenon of cultural diversity. With the Trinity as point of departure, respect for cultural diversity and plurality as a shared value will now be discussed, evaluated and grounded.

\section{Creating Father}

According to VanDrunen (2009:33), the covenant of God the Father with humankind in Genesis 1-11 forms, firstly, the background for understanding a global bioethics (DomNwachukwu \& Lee 2014:loc 1615). The Bible reveals the development of universal justice in order to govern the diverse and broken human existence after the fall into sin. König (2010:113-114) and Van Wyk (1998:176) point out that Genesis 1-11 is a universal human history (before the calling of Abraham) and must be understood as follows: on the one hand, according to Genesis 9:16, God is universally involved in a covenant with all humankind from the beginning; on the other hand, Genesis 1-11 deals with shared values (Kelly, Magill \& Ten Have 2013:15; Vorster 2004:42). VanDrunen (2009) explains the statement further in his book Bioethics and the Christian life:

Genesis 4:15 and 9:6 are particularly relevant. In both of these texts God ordained a system of human justice not as the sole possession of those who believed in him but as the common possession of the human race. (pp. 31-33)

Because God is good to all people (Mt 5:44-46; Ps 145:9), the human being has the command to do good to all people (Gl 6:10). The human being has to promote the common good (Douma 1990:54). Genesis 1-11 indicates that God will provide authority in the world in the form of universal codes, such as the UDBHR and Article 12, with a view to protect the human being and creation against evil and to promote general well-being (Vorster 2007:108).

Secondly, God the Father is the origin of the unity for all human beings in the world. God created the human in his image (Gn 1:2, 27-28). Therefore, if the Trinity is taken as belief, the image of the human as the image of God implies in itself the unity of all human beings, that is, just like there is one God, all human beings are one. The idea of the unity of humankind is confirmed by Paul in Acts 17:22-32 (Fensham 2004:896; Maggay 2017:loc 868; Stott et al. 2006:287). Paul refers to the unity when he argues that God 'made of one blood all nations of men' (Ac 17:24, 26-KJV; DomNwachukwu \& Lee 2014:loc 1492; Hays 2003:59; Heyns 1989:8). In this statement, the equality and human dignity of all people are indicated. Stott et al. (2006:287) has the following comment saying, 'Being equally created by him and like him, we are equal in his sight in worth and dignity, and, therefore, have an equal right to respect and justice'.

No human being or group is inferior or superior in comparison to another, which already means that all people and groups have the right to equal recognition or respect (Heyns 1989:8). The conclusion of Stott et al. (2006:291; cf. also Lausanne Committee for World Evangelization 1978) was:

Because of the unity of humankind, we demand equal rights and equal respect for ethnic minorities. Because of the diversity of ethnic groups, we renounce cultural imperialism and seek to preserve all those riches of culture which are compatible with Christ's lordship.

From the perspective of creation, thirdly, the Bible focuses not only on the unity of humankind but also on cultural diversity. God created the human being in his image (Gn 1:2, 27-28) and, again, if the Trinity is accepted as belief, the image of the multiple existence of God implies in itself the possibility of cultural diversity (DomNwachukwu \& Lee 2014:loc 1463). Once again, a confirmation is found in the words of Paul when he points out that God 'made every nation of men, that they should inhabit the whole earth' (Ac 17:26 - KJV; see also Dt 32:8; Rynkiewich 2011:199). Cultural diversity is an image of the Triune God in the world.

Cultural diversity is the result of obedience to the command of God and of human freedom. On the one hand, the first command of God to the image-bearing human being was to fill the earth (Gn 1:28) and it was repeated after the fall into $\sin$ (Gn 9:1-7; Frame 2008:862). Just like God 'moved from the heaven to the earth', the created human being had to fill the earth and procreate people like God. The execution of the command to fill the earth is the origin of language and cultural diversity in the form of individuals and groups as described in Genesis 10 (Frame 2008:856; Lausanne Committee for World Evangelization 1978; Romero 1996:189; Sheffield 2001:46). Maggay (2017:loc 849) says, 'Genesis 10, quite significantly, recognises the primordial diversity of culture ... Most scholars glossed over or ignored the alternative tradition in Genesis 10'. Unique characteristics of different cultures (individuals and groups) come into being because of the interaction of countries, climate and people (because of movement) (Stott et al. 2006:288).

On the other hand, God gives and respects human freedom; this is deduced from the fact that God did not prescribe of which of the approved trees fruit could be eaten (Gn 2:16-17) or what specific names had to be given to the animals (Gn 2:19). This fact entails a large degree of flexibility in the cultural development of humankind. Chan (s.a.) is of the opinion that the development of humankind and decisionmaking over time had to lead to different methods of problem-solving and different forms of work, games, art and science. Diversification as a product of human freedom has been unavoidable irrespective of obedience to the command of God to fill the earth. Cultural diversity is not the result 
of sin. The fundamental problem of Genesis 11 is the effort to ignore and not to acknowledge the command to diversify (Gn 1:28, 11:4) and consciously form a unity characterised by uniformity (Gn 11:6; Sheffield 2001:46). God rejected this denial of cultural diversity by language confusion (Gn 11:7), which resulted in humankind spreading over the earth again (Gn 11:8; Maggay 2017:loc 941, 968-974; Rynkiewich 2011:199-201; Sheffield 2001:47). In this way, cultural diversity was respected by God and confusion was the result of the denial and disrespect for pluralism.

The acknowledgement of and respect for cultural diversity is found right through the Old Testament. That foreigners could eat unclean meat in Israel (Dt 14:21) and were not obliged to celebrate the Passover are indications of the freedom of eating habits among the Jews and may be regarded as a concession and respect for cultural diversity. In addition, there is the interpretation that the foreigners even had cultural rights (Dt 24:17; Maggay 2017:loc 1615). If cultural diversity is accepted as a point of departure, the acknowledgement of diverse identities of individuals or groups is implied. The people of Israel in the Old Testament provide a guideline in understanding cultural identity in answering the questions of who, where and from where you are ethnically, territorially and historically (Lausanne Committee for World Evangelization 1978). If the Biblical positive evaluation of cultural diversity is accepted, pluralism is an unavoidable consequence (Stott et al. 2006:79).

To this culturally diverse humankind as the image of God is given the command and ability, fourthly, not only to fill the earth but also to cultivate it or to create cultural products (Gn $1: 28,2: 15)$. In the same way as God formed the earth from chaos (formlessness) and filled the empty spaces (with celestial bodies, living creatures), the diverse humankind has the task to cultivate the given nature. Cain built a city; some lived in tents and farmed with animals. Others developed music instruments and implements (Gn 4:20-22; Frame 2008:859). The term culture is derived from the Latin word colere, which has the broad meaning 'to cultivate' (Webber 2004:17-18). The concept of culture is difficult to describe. In general, a distinction is made between nature and culture, where nature refers to what God has given or created, and culture is things that are made or acquired through learning by humans. If cultural diversity is accepted as a point of departure, the implication is also diversity in producing cultural products. Diverse individuals and groups as the image of God have a created impulse to express themselves in diverse ways in art and architecture; music and theatre; science and engineering; agriculture and industry; philosophy and religion; education and medicine; sports and recreation; and law and government (DomNwachukwu \& Lee 2014:loc 1492; Heyns 1989:10; Maggay 2017:loc 600, 879; Stott et al. 2006:288).

\section{Recreating Son}

Subsequently, the focus is on cultural diversity and pluralism from a Christological or recreating perspective. 'Christology unarguably has an important place in any theology of diversity', is the opinion of Gibson (2012). The incarnation of Christ by becoming man indicates in the first place respect for and acknowledgement of human culture because Christ followed specific human cultural customs (Mt 3:15-17; Fensham 2004:898). In this connection, Maggay (2017) exclaims:

I have never ceased to be amazed that Jesus, the man for all cultures and all times, was a Jew ... The notion that nationality is incidental and the place we live in merely an address is unsupported by Scripture's emphasis on the incarnation as a model of life and witness. (loc 2310-2324)

Gibson (2012:432) finds, in the second place, a Christological grounding of diversity in the universal and inclusive 'all' texts, in which Christ does not exclude any group or culture (Mt 11:28, 29:19-20; Mk 11:27). Christ's commission to the church is to be his witnesses to the 'uttermost part of the earth' (Ac 1:8-KJV). The general scope of the gospel is underlined by Paul when he points out that the gospel was preached beforehand to Abraham with the promise that all nations will be blessed through him (Gn 12:3; Gl 3:8), with the hope of the universal reconciliation of all people (Jn 12:32; Col 1:13-21; Peters 1972:83-156).

Thirdly, there are also the examples where Christ interacts with people of different cultures and identities. An example is the respect of Jesus for the Samarian community (Sheffield 2001:54). The Samarians were a community of mixed races and they lived in continuous underlying racial tension with the Jewish community. Despite the pressure of his 'own people', Jesus did not separate himself from the Samarians but reached out to them (Jn 4:9, 39-40) and his actions were to their benefit (Lk 17:15-16). Moreover, Jesus travelled through areas outside the Jewish territory (Mk 7:31) and used people outside his faith tradition as examples (Lk 9:7; Sheffield 2001:54). According to Hays (2003:172), Christ demonstrated the equality of all populations by his recognition of diversity.

According to Vorster (2004:82), the recreating work of Christ implies, fourthly, that the believer as a new human being stands in a loving relationship with Christ and his fellow human being (2 Cor 5:17). Ephesians 2:14-16 has the interpretation that the death of Christ has cultural meaning: on the cross the animosity between cultural diversity (Jew and heathen) was destroyed resulting in the fact that the new human being can or has to love and respect cultural diversity. Cultural diversity is not a threat anymore. For this reason, it is found that Paul indicates in 1 Corinthians 9:19-20 that cultural diversity has to be taken into account and be respected and that there has to be an awareness of its importance to people (Frame 2008:866). Paul is willing to subject himself to the culture and convictions of people that are different from him, when he says that for the Jews he has become like a Jew by accepting the Jewish socio-cultural practices (vs. 20), for example, by shaving his hair (Nm 6:18; Ac 21:26; Maggay 2017:loc 1834). This respect and sensitivity for cultural diversity is found right through the New Testament. Two examples can be cited. The first is John describing Christ as the 'Word' of God (Jn 1:1) to accommodate 
the logos concept of Greek philosophy. The second is Paul's reference to Greek poetry in Acts 17:28, where he says, 'For in Him we live, and move, and have our being; as also certain of your own poets have said, "For we are also His offspring"'. In mediating conflict, the apostle respected diversity. He made sure that the young men who had to take care of the Greek-speaking widows had names that indicated they had the same cultural identity (Ac 6:5). The converts, who were exempted from circumcision, were expected to be culturally sensitive by abstaining from cultural practices that the Jews might have found repugnant (Ac 15:19-20; Rm 14:6-7, 14; Stern 1988:154-157).

\section{Blessing Spirit}

An eschatological grounding for cultural diversity can also be presented. The Spirit of God wants diversity is the view of Congdon (2016:loc 1298). The pouring out of the Spirit in Acts 2 is first the beginning of the church as unity and diversity (DomNwachukwu \& Lee 2014:1850; Naudé 2016:17). The diversity of cultures is confirmed when the Spirit is poured out on 'all people' - Parthians, Medes and Elamites, residents of Mesopotamia, Judea and Cappadocia, Pontus and Asia, Phrygia and Pamphylia, Egypt and the parts of Libya and Rome (Ac 2:10, 17). The multiplicity of cultures and languages is recognised as a blessing. The forming and recognition of diversity as a command from God in Genesis 1, 10 and 11 is reconfirmed in Acts 2 as the will of God. According to Maggay (2017:loc 2038), God indicates a way of essential existence by the events in Acts 2. Congdon (2016) concludes as follows:

The Spirit of Pentecost blesses the languages - and, by extension, the sociocultural frameworks - of 'every nation under heaven' (Acts 2: 5) and grants the community an eschatological vision of new creation in which 'a great multitude ... from every nation, from all tribes and peoples and languages' are gathered together, unified precisely in their diversity (Rev 7: 9) ... Pentecost is the blessing of Babel's curse; it sanctifies the very diversity that is the cause of our cultural fragmentation and miscommunication. (loc $1459,4913)$

The first letter to Peter confirms, secondly, the diversity of the church and acknowledges the Spirit as the origin and creator of diversity when believers from diverse areas are made part of the church (1 Pt 1:1-2; DomNwachukwu \& Lee 2014:loc 1730-1737). The Spirit acknowledges and collects diversity in the reference to the church as a body that consists of many different people, such as Jews and Greeks (1 Cor 13:12-15). The work of the Spirit is not only that of forming communities and uniting diversity (2 Cor 13:13) but also that of creating and using diversity, as Paul indicates that the Spirit gives a variety of gifts of grace (1 Cor 12:3; Sheffield 2001:57). What is important and connected to the motif of creation is that the church is not only a diverse entity but also forms a unity because the one church is made up of all nations (Jews or Greeks), all genders (men or women) and all social groupings (slaves or freemen), where all now form the one progeny of Abraham (Gl 3:26-29). In the one church, unity is applied in such a way that cultural identity is respected (Naudé 2016:17).
The eschatological perspective offers, thirdly, the glorious expectancy of the new eternal life together with God. Two matters are important here regarding cultural diversity. The first vision we find is the acknowledgement and gathering of a unity and diversity of believers in a glorious state of salvation and peace together with God. This large multitude of believers come from all nations, tribes, peoples and languages and stand as a unity before the throne of God ( Rv 7:9; Gibson 2012:443). This phrase indicates a socio-political difference ('nations'), as well as cultural ('kindred'), ethnic ('people') and language ('tongues') diversity (Sheffield 2001:50). From this description, it can be deduced that cultural diversity on earth is not a casualism (Maggay 2017:loc 2282), but an essentiality that would remain an unchanged reality up to the end (DomNwachukwu \& Lee 2014:loc 2121; Naudé 2016:18). Together with this conclusion, it is also found that Scripture has a positive evaluation of cultural diversity, when John points out that the New Jerusalem will be enriched when 'the glory and honour of the nations will be brought into it' (Rv 21:26). However, it will be a cultural diversity that will be purified from all sinful aspects (Rv 21:27; Sheffield 2001:50). Referring to this point, Stott et al. (2006:288) says, 'If they will enrich human life and community in the end, they can begin to do so now'.

Briefly summarised, one can say that in light of the presentation of the Trinitarian grounding of cultural diversity, it is clearly seen that a Protestant ethics acknowledges the importance of cultural diversity as value and that it wholeheartedly supports the idea that cultural diversity in the bioethical area has to be seriously considered. Denying identity and ignoring cultural diversity afflicts human dignity and equality and is a form of discrimination.

\section{The priority}

In the discussion of Article 12, it has been indicated that universal principles enjoy priority before respect for cultural diversity. Can this view be grounded from a Biblical perspective? Heyns (1989:9-10) is of the opinion that it is possible and sees the particular and universal not at the same normative level. He regards God and the unity of mankind, and with that the universal, as priority. The following Biblical arguments support the prioritising of the universal above the particular.

Maggay (2017:loc 3045) firstly makes the interesting observation that the creation narrative links cultural diversity and cultural creation with governance (Gn 1:28, 2:15), which indicates that culture is not an own legislating normative reality, but has to be governed and regulated. The Lausanne Committee for World Evangelization (1978) states a similar idea in connection with the human being, who as the image of God has to manage culture by means of the universal norms of God. Secondly, Karl Barth (1976:311) points out that the first commandment of God is universal in nature; and as universal directive (Gn 9:6) it exits and functions before any particular and cultural standards (Gn 12). From Adam to Noah, there is no mention of the will of God directed at the 
particular, but it is indeed directed at the universal. Thirdly, Volf $(1996: 39,44-45)$ refers to Genesis 12 in connection with secondary related matters, which indicate that unity and cultural diversity do not lie at the same normative level. He refers to Abraham (Gn 12), who had to leave cultural and family ties behind (Jos 24:2) and committed himself to the universal God, who is the God of all cultures and families (cf. also Mk 1:16-20). The universal is more important and transcends the particular and cultural. Together with this, the fact that faith, not genealogy, creates a relationship with the universal God indicates that the value of culture should be further judged in relation to universal values (Gl 3:7). Fourthly, cultural diversity is connected with sin (Frame 2008), which implies that culture is not perfect as regards truth, beauty or worth (Lausanne Committee for World Evangelization 1978). Because judgement is mentioned in the context of the cultivation of the earth (Gn 3:17), that is, the specific sphere where cultural responsibility is practised $(\mathrm{Gn}$ $2: 15)$, the conclusion is that the cultural expression of humankind has been afflicted by sin (Webber 2004:40). The Biblical view of cultural diversity includes its insignificance (Is 40:17) that people and nation are carriers and doers of sin (Lk 24:47) and that they can even be evil (Rv 17:15-16). According to Volf (1996:52), it means the evil in culture must be condemned. The judgement starts at the house of God or the own culture (1 Pt 4:10) from which the evil must be driven out (Rv 20:10; Sheffield 2001:58-59). In his understanding of Genesis 6:5-6, Frame (2008:858) is of the opinion that 'God himself was the first critic of culture' and therefore the Bible and the church warn humankind continuously against abominable cultural practices (Dt 18:9-11) on the basis of the universal ban (Dt 18:12). Intercession has to be done for vulnerable people who are harmed by cultural practices (Pr 31:8-9) by convincing a specific culture that human rights are good and are intended to promote the well-being of the human being (Dt 5:29, 10:13, 12:28). Fourthly, although cultural diversity is very important and has to be respected, according to Naudé (2016:17), Christ denied its absolute character when Paul indicates that Christ did not hold on to his 'culture', character, nature or identity in specific circumstances but that He regarded those things as worthless and even abandoned them (Phlp 2:5-8), something that Paul and the believers can follow Him (2 Cor 5:17; Phlp 3:4-9; 1 Cor 9:19-20). They can do it because they have a new identity in Christ (Gl 2:20), where Christ has the highest worth (Phlp 3:8). Christ as the universal Word of God is more important than the particular culture of the human being (Lausanne Committee for World Evangelization 1978). In the fifth place, prioritising of universal values means abandoning ethical relativism. The danger of ethical relativism is explained as follows by Fensham (2004:896): 'Do assumptions of cultural relativity encourage uncritical acceptance of injustice and exploitation within one's own culture, including Western culture? How does the biblical prophetic call for justice fit with a blanket acceptance of cultural relativity?'

Briefly summarised, it can be said that in the light of the above-mentioned theological argumentation, the prioritising of universal shared values before the particular cultural values in the UNESCO Declaration can be defended.

\section{Synopsis}

In the development and acceptance of Article 12 of the UDBHR, UNESCO did not involve the Protestant faith tradition in the consultation process (other traditions were indeed consulted). This brings the universality (UNESCO perspective) as well as the acceptability of the Declaration and its principles (democratic perspective) into question. In order to address this issue, it is necessary to involve the Protestant tradition in the discourse by presenting own reasons that support the universal principles in the Declaration (theological perspective). This discourse has shown that respect for cultural diversity, pluralism and the priority of universal shared values can be grounded from a Trinitarian perspective; therefore, the appeal of the Declaration to consider this principle seriously in the field of bioethics can be supported by the Protestant religious tradition.

\section{Acknowledgements Competing interests}

The author declares that he has no financial or personal relationships which may have inappropriately influenced him in writing this article.

\section{References}

Alvarez, A., 2016, 'Cultural diversity', in H. Ten Have (ed.), Encyclopedia of globa bioethics, pp. 781-790, Springer International, Cham.

Barth, K., 1976, The doctrine of God, vol. 3, Clark, Edinburgh.

Burton, B., 2002, 'Proposed genetic database on Tongans opposed', British Medical Journal 324(7335), 443-443. https://doi.org/10.1136/bmj.324.7335.443/a

Chan, F., s.a., Biblical materials for a theology of cultural diversity: A proposal, viewed 20 January 2017, from https://www.nyack.edu/content/FaithfulNarrative

Chuwa, L., 2014, African indigenous ethics in global bioethics: Interpreting Ubuntu, vol. 1, Springer Science+Business Media, Dordrecht.

Congdon, D.W., 2016, The God who saves: A dogmatic sketch, Wipf \& Stock, Eugene, $\mathrm{OR}$, viewed n.d., from www.amazon.com

DomNwachukwu, C.S. \& Lee, H.K., 2014, Multiculturalism: A shalom motif for the Christian community, Wipf \& Stock, Eugene, OR, viewed n.d., from www.amazon. com

Douma, J., 1990, Ethiek en recht, Van den Berg, Kampen.

Fensham, C., 2004, Culture, in H.J. Hillerbrand (ed.), The encyclopedia of Protestantism, Routledge, New York.

Frame, J., 2008, The doctrine of the Christian life, P\&R, Phillipsburg.

Gallagher, C.M., 2014, 'A Christian consideration of human vulnerability in healthcare and research', in J. Tham, A. Garcia \& G. Miranda (eds.), Religious perspectives on human vulnerability in bioethics, pp. 135-141, Advancing global bioethics 2 Springer, Dordrecht.

Garcia, A. \& Monlezun, D., 2016, 'Casuistry', in H. Ten Have (ed.), Encyclopedia of global bioethics, pp. 440-450, Springer International, Cham.

Gibson, J.K., 2012, 'A Pneumatological theology of diversity', Anglican Theological Review 94(3), 429-449.

Hays, J.D., 2003, From every people and nation: A Biblical theology of race, Apollos, Leicester.

Heyns, J.A., 1982, Teologiese etiek, vol. 1, N.G. Kerkboekhandel, Pretoria.

Heyns, J.A., 1989, Teologiese etiek, dl. 2/2, Sosiale etiek, N.G. Kerkboekhandel, Pretoria.

Hollinger, D.P., 2008, Choosing the good: Christian ethics in a complex world, Baker Academic, Grand Rapids, MI.

IBC, 2004, Eleventh Session International Bioethics Committee of UNESCO (IBC), UNESCO Publishing, Paris, 23-24 August 2004, viewed 18 November 2013, from ReportCIB11_en.pdf 
IBC, 2008, Report of the International Bioethics Committee of UNESCO (IBC) on Consent, viewed 18 November 2013, from http://unesdoc.unesco.org/images/ Consent, viewed 18 Novem

IBC, 2013, Report of the IBC on traditional medicine systems and their ethical implications, UNESCO Publishing, Paris, viewed 08 August 2015, from http:// unesdoc.unesco.org/images/0021/002174/217457e.pdf

Kelly, D., Magill, G. \& Ten Have., H., 2013, Contemporary Catholic health care ethics, 2nd edn., Georgetown University Press, Washington, DC.

König, A., 2010, Alle paaie lei na Jesus, CUM, Vereeniging.

Langlois, A., 2013, Negotiating bioethics: The governance of UNESCO's bioethics programme, Taylor and Francis, London.

Lausanne Committee for World Evangelization, 1978, The Willowbank report Consultation on Gospel and culture, viewed 20 January, from https://www. lausanne.org/content/lop/lop-2

Lorenzen, T., 2009, 'Justice anchored in truth: A theological perspective on the nature and implementation of justice', International Journal of Public Theology 3(3), 281-298. https://doi.org/10.1163/156973209X438256

Macaleer, R.D., 2014, The New Testament and bioethics: Theology and basic bioethics principles, Pickwick, Eugene, OR

Macklin, R., 2014, 'Respect for cultural diversity and pluralism', in H.A.M.J. Ten Have \& B. Gordijn B. (eds.), Handbook of global bioethics, pp. 153-167, Springer Science + Business Media, Dordrecht.

Maggay, M.P., 2017, Global kingdom, global people: Living faithfully in a multicultural world, Langham Creative Projects, Kindle edn., viewed May 2017, from www. amazon.com

Martin, J.F., 2014, 'Privacy and confidentiality', in H.A.M.J. Ten Have \& B. Gordijn (eds.), Handbook of global bioethics, Springer Science + Business Media, Dordrecht.

Naudé, P., 2016, Pathways in ethics: Justice, interpretation, discourse, economics, vol. 9, SUN MeDIA, Stellenbosch.

Pauls, M. \& Hutchinson, R., 2008, 'Protestant bioethics', in P.A. Singer \& A.M. Viens (eds.), The Cambridge textbook of bioethics, Cambridge University Press, Cambridge.

Peters, G.W., 1972, A Biblical theology of missions, Moody Publishers, Chicago, IL.

Rawls, J., 1993, Political liberalism, Columbia University Press, New York.

Revel, M., 2009, 'Article 12: Respect for cultural diversity and pluralism', in H. Ten Have \& M. Jean M. (eds.), The UNESCO universal declaration on bioethics and human rights: Background, principles and application, pp. 199-209, Ethics series, rights: Background, pring
UNESCO Publishing, Paris.

Rivard, G., 2009, 'Article 11: Non-discrimination and non-stigmatization', in H. Ten Have \& M. Jean (eds.), The UNESCO universal declaration on bioethics and human rights: Background, principles and application, pp. 188-198, Ethics series, UNESCO Publishing, Paris.

Romero, D.F., 1996, 'The church's struggle with diversity', International Review of Mission 85(337), 189-204. https://doi.org/10.1111/j.1758-6631.1996.tb03478.

Rusthoven, J.J., 2014, Covenantal biomedical ethics for contemporary medicine: An alternative to principles-based ethics, Wipf \& Stock, Eugene, OR.

Rynkiewich, M., 2011, 'Culture', in J.B. Green, J.E. Lapsley, R. Miles \& A. Verhey (eds.), Dictionary of Scripture and ethics, Baker Academic, Grand Rapids, MI.

Sheffield, D., 2001, 'Toward a theology of diversity: A Christian response to multiculturalism', Didaskalia 13(1), 39-59.

Shickle, D., 2014, 'Biobanking', in H.A.M.J. Ten Have \& B. Gordijn (eds.), Handbook of global bioethics, pp. 485-503, Springer Science + Business Media, Dordrecht.

Stern, D.H., 1988, Messianic Jewish manifesto, Jewish New Testament Publications, s.n., s.l.

Stott, J.R.W., McCloughry, R., Wyatt, J. \& Stott, J.R.W., 2006, Issues facing Christians today, 4 th edn., fully rev. and updated by R. McCloughry; with a new chapter by J. Wyatt, Zondervan, Grand Rapids, MI.
Taylor, C., 1994, 'Politics of recognition', in A. Gutmann (ed.), Multi-culturalism, pp. 25-75, Princeton University Press, Princeton, NJ.

Ten Have, H., 2011, Bioethiek zonder grenzen: Mondialisering van gezondheid, ethiek en wetenschap, Valkhof Pers, Antwerpen.

Ten Have, H., 2016, Global Bioethics: An introduction, Taylor \& Francis, London.

Ten Have, H. \& Gordijn, B., 2014, 'Future perspectives', in H.A.M.J.Ten Have \& B. Gordijn (eds.), Handbook of global bioethics, pp. 829-844, Springer Science + Business Media, Dordrecht.

Ten Have, H. \& Jean, M., 2009, 'Introduction', in H. Ten Have \& M. Jean (eds.), The UNESCO universal declaration on bioethics and human rights: Background, principles and application, pp. 17-57, Ethics series, UNESCO Publishing, Paris.

Tham, J., 2014, 'Introduction: The principle of vulnerability: Meeting ground of six religions', in J. Tham, A. Garcia \& G. Miranda (eds.), Religious perspectives on human vulnerability in bioethics, Advancing global bioethics 2, pp. 1-7, Springer, Dordrecht.

UNESCO, 2002, UNESCO universal declaration on cultural diversity, adopted by the 31st Session of the General Conference of UNESCO, Paris, 02 November 2001 viewed 18 November 2013, from http://www.unesco.org/new/fileadmin/ MULTIMEDIA/HQ/CLT/pdf/5_Cultural_Diversity_EN.pdf

UNESCO, 2005, Records of the General Conference, 33rd session, Paris, 3-21 October 2005, vol. 1, Resolutions, viewed 18 November 2013, from http://unesdoc. unesco.org/images/0014/001428/142825e.pdf

UNESCO, 2006, Universal declaration on bioethics and human rights, viewed 18 November2013, from http://unesdoc.unesco.org/images/0014/001461/146180e. pdf

UNESCO, 2008, Bioethics core curriculum, Section 1, Syllabus Ethics Education Programme, Sector for Social and Human Sciences Division of Ethics of Science
and Technology, viewed 18 November 2013, from http://unesdoc.unesco.org/ and Technology, viewed 18 Novem
images/0016/001636/163613e.pdf

UNESCO, 2011, Bioethics core curriculum, Section 2, Study Materials Ethics Education Programme Version, viewed 18 November 2013, from http://unesdoc.unesco. org/images/0021/002109/210933e.pdf

UNESCO Chair in Bioethics Haifa, 2016, Casebook on bioethics for judges, Israel National Commission for UNESCO, Jerusalem, viewed 12 January 2007, from http://www. unesco-chair-bioethics.org/?mbt_book=casebook-on-bioethics-for-judges

VanDrunen, D., 2009, Bioethics and the Christian life: A guide to making difficult decisions, Crossway, Wheaton

Van Leeuwen, E., 2014, 'Protestantism', in H.A.M.J. Ten Have \& B. Gordijn (eds.), Handbook of global bioethics, pp. 419-427, Springer Science + Business Media, Dordrecht.

Van Wyk, J.H., 1998, Debat oor menseregte: Etiek in eenvoud, pp. 174-176, Gesprekke oor morele vraagstukke, Potchefstroomse Teologiese Publikasies, Noordbrug.

Volf, M., 1996, Exclusion and embrace: A theological exploration of identity, otherness, and reconciliation, Abingdon Press, Nashville, TN.

Vorster, J.M., 2004, Ethical perspectives on human rights, Potchefstroom Theological Publications, Potchefstroom.

Vorster, J.M., 2015, Christelike etiek in 'n sekulariserende samelewing, AOSIS, Durbanville.

Vorster, N., 2007, Restoring human dignity in South Africa: Christian anthropology in a new dispensation, Potchefstroom Theological Publications, Potchefstroom.

Waldron, J., 2010, 'The image of God: Rights, reason, and order', in J. Witte \& F.S Alexander (eds.), Christianity and human rights: An introduction, Cambridge University Press, Cambridge.

Wallace, K.A., 2009, 'Common morality and moral reform', Theoretical Medicine and Bioethics 30(1), 55-68. https://doi.org/10.1007/s11017-009-9096-2

Webber, R.E., 2004, The secular saint: A case for evangelical social responsibility, Wip \& Stock, Eugene, $\mathrm{OR}$

Wenar, L., 2017, 'John Rawls', in The Stanford Encyclopedia of Philosophy, Spring edn. E.N. Zalta (ed.), viewed 22 May 2017, from https://plato.stanford.edu/archives/ spr2017/entries/rawls/ 